\title{
Nurses- puerperal mothers interaction: searching for cultural care
}

\author{
Interação enfermeiros e puérperas: na procura de um cuidado cultural \\ Interacción enfermeras y madres: en la búsqueda de un cuidado cultural
}

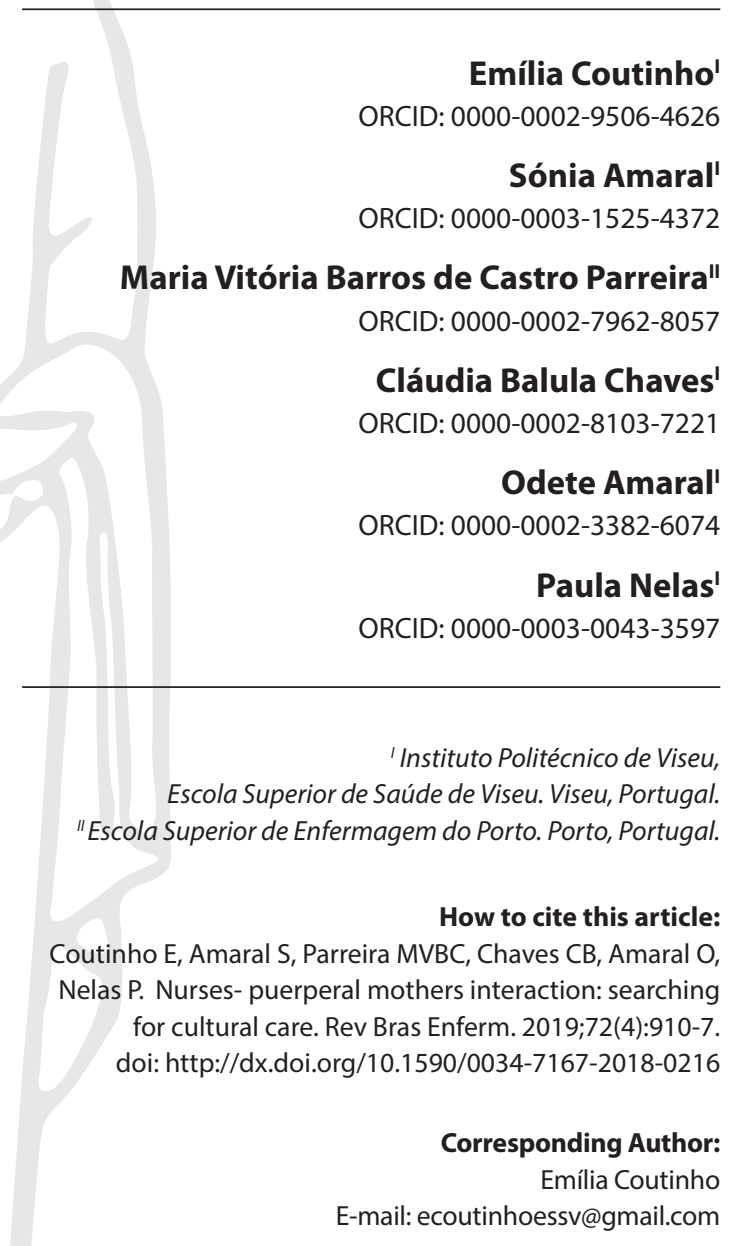

Submission: 05-04-2018

Approval: 08-18-2018

\begin{abstract}
Objective: To identify the importance of the cultural care dimension in the nursepuerperal mother interaction. Method: Qualitative study based on content analysis. To collect data, 36 semi structured interviews were applied ( 21 nurses and 15 women who had recently given birth). The participants' free and informed consent was ensured and all ethical requirements were respected. Data analysis was supported by NVivo 10 software. Results: The following categories were considered the most relevant: (i) nurses' attitudes that puerperal mothers consider crucial in health care provision; (ii) nurses' cultural competence; (iii) language resources used by nurses in their interaction with people from other cultures; (iv) the limitations that were observed during nursesnew mothers interactions. Conclusion: Evidence shows that, generally speaking, nurses claim to provide personalized health care assistance. However data revealed that the kind of interaction observed between nurses and women who had just given birth has not always been the most effective and that the former often show they lacked the appropriate cultural competence to deal with the latter's expectations and needs. Descriptors: Cultural Competence; Puerperium; Nurses; Communication; Attitude.
\end{abstract}

\section{RESUMO}

Objetivo: Identificar a dimensão do cuidado cultural na interação entre enfermeiras e puérperas. Método: Estudo qualitativo assente na análise de conteúdo. Na colheita de dados se utilizou a entrevista semiestruturada, a 21 enfermeiras e 15 puérperas num total de 36 entrevistadas. Se assegurou o consentimento livre e esclarecido bem como respeitaram-se todos os requisitos éticos. A análise de dados foi suportada pelo NVivo 10. Resultados: Destacaram-se as categorias: (i) Atitudes das enfermeiras que as puérperas reconhecem imprescindíveis no processo de cuidar; (ii) Exercitar a competência cultural; (iii) Recursos linguísticos utilizados pelas enfermeiras na interação com pessoas de outras culturas; (iv) Constrangimentos manifestados nas interações enfermeiras e puérperas. Conclusão: Conclui-se que apesar das enfermeiras, ao nível discursivo, afirmarem que cuidam de forma personalizada, os dados revelaram que nem sempre as enfermeiras foram eficazes nas interações com as puérperas, de forma a demonstrarem a competência cultural, num estadio considerado culturalmente consciente.

Descritores: Competência Cultural; Puerpério; Enfermeiras; Comunicação; Atitude.

\section{RESUMEN}

Objetivo: identificar la dimensión de la competencia cultural en la interacción entre enfermeras y mujeres que hayan dado a luz recientemente. Método: estudio cualitativo basado en el análisis de contenidos. En la recopilación de datos se utilizó la entrevista semiestructurada. Han participado 21 enfermeras y 15 madres en un total de 36 entrevistas. Se aseguró el consentimiento previo, libre e informado de todos los participantes y todos los requisitos éticos fueron respetados. El análisis de datos fue apoyado por el programa NVivo 10. Resultados: las siguientes categorías fueron destacadas: (i) actitudes de las enfermeras que las madres creen ser indispensables en el proceso de cuidar; ii) el ejercicio de la competencia cultural; iii) los recursos lingüísticos utilizados por las enfermeras en la interacción con personas de otras culturas; iv) restricciones y problemas observados en las interacciones entre enfermeras y madres. Conclusión: se concluye que, en general, las enfermeras afirman que cuidan de sus pacientes de manera personalizada. Todavía, los datos revelaron que las interacciones entre enfermeras y madres son a menudo poco eficaces y a las enfermeras les resulta difícil demostrar su competencia cultural. Descriptores: Competencia Cultural; Puerperio; Enfermeras; Comunicación; Actitud. 


\section{INTRODUCTION}

Nursing is more than anything else a profession where the most important facet is providing care in transcultural and intercultural contexts and that assumes a central role in the promotion of meaningful and congruent care, respecting the cultural values and lifestyles of individuals, families, and communities ${ }^{(1)}$. Most of the understandings of transcultural nursing people have nowadays, as a consequence of the development of knowledge in the field of health care provision and cultural competence is due to Madeleine Leininger, a nurse and anthropologist and the author of the Middle Range Nursing Theory and of Culture Care Diversity and Universality: a Theory of Nursing.

She was the driving force behind the process that turned nursing knowledge into a discipline and a profession, through the use of ethnographic research, of her Ethnonursing Research Method and of herThree Phase Observation-Participation-Reflection Enabler, that were crucial to better understand the influence played by social and cultural factors on people's care beliefs and behaviours.

Her work enabled the development of a sense of cultural understanding and awareness that is pivotal to preserve a sense of multicultural identity and minimize cultural imposition. It also helped nurses to acquire greater knowledge about themselves and consequently become more aware of their own culture visà-vis others. That awareness is crucial to overcome ethnocentric positions and to eliminate prejudice based on subjective culture and on others shaped by society itself.

At the time, this vision was important for the nurse to start accepting her patients as cultural beings, with a unique and personal vision of the world based on their cultural beliefs, values, customs and practices, instead of focusing solely on the patients' problems and on their bio-physiological needs. This new perspective allowed the nurse to become culturally competent as she started acting as a link between health care and the patient's culture. This kind of care provision became the essence of the profession.

As they were witnessing the birth and the development a new way of thinking that would shape nursing practice, other nursing theorists adopted these and other principles based on the nursing metaparadigmatic concepts: person, health, environment and nursing care. Those theorists (among which was Larry Purcell) gave birth to other transcultural nursing models that materially contributed to cultural understanding and cultural competence in nursing ${ }^{(2)}$.

It is no longer enough for nurses to grasp concepts in a discursive way. In today's society, cultural competence needs to be fully integrated and implemented in nurses' daily practice and to have a real critical and conscious impact on their action since providing health care involves a clear understanding of the human essence, the awareness of self-existence and of the existence of the Other in order to choose the right course of action ${ }^{(3)}$.

In this context, cultural competence is a crucial component of effective and culturally responsive care ${ }^{(4)}$. It is therefore of critical importance to be aware of the cultural context, of the values, beliefs, rituals and way of life of the individuals and of their families as to enable the construction of a new paradigm of care that will incorporate a culturally competent approach, that aims at promoting health, quality of life and well-being and that will allow the construction of emancipatory practices involving puerperal mothers and couples to help minimize the negative effects caused by knowledge deficit and mobilize internal resources in order to overcome the difficulties that are part of any childbirth and delivery process.

In this context, one has to consider not only the individual specificities that make each person unique and different, but also the migratory flows occurring in Portugal and that give rise to a heterogeneous population who requires health care services and whose presence is enough to justify the urgent need to recognize the strategies used to deliver culturally competent care, from both the caregiver's and the patient's perspectives. This may give nurses the opportunity to rely on their cultural competence to provide the puerperal mother with the fitting health care throughout the whole childbirth process ${ }^{(3)}$.

In health care environments in general, and particularly in maternal and obstetric health care, women who have just given birth are faced with a new culture in which they may have to deal with cultural assimilation phenomena ${ }^{(5)}$ or in which they may come to experience the sharing and exchange that take place during social interactions in an intercultural environment, a multicultural community where tolerance, understanding and the respect for what is different is a reality in which people never lose the specific features of their culture of origin. It should be stressed that knowledge and practices that come from education as well as family and social rituals are essential for maintaining their beliefs and values and their culture of origin, that are paramount to define their way of thinking, of being and of acting.

Campinha-Bacote, in her model of cultural competence ${ }^{(4)}$, supports the notion of cultural competence as the ongoing process in which the health care provider continuously strives to achieve the ability and the willingness to effectively work within the cultural context of the individual, the family and the community. This model requires nurses to look at themselves as if they are culturally competent instead of being culturally competent. Purnell and Paulanka ${ }^{(6)}$ highlight the importance of cultural competence which begins with self-awareness and which grows within an integrated set of knowledge, skills and attitudes.

In other words, this model is proposed as an organizing framework that nurses can use to perform cultural assessments. The ethnographic approach is used to promote cultural understanding, well-being and health promotion. Within the model, there are 12 domains that include different types of understanding of what health care and disease may represent. Therefore, a culturally competent health care provider should assess all applicable domains for each client that might be influenced by their living environment ${ }^{(7)}$.

Barimani et al. ${ }^{(8)}$ claim, in their study, that a large percentage of puerperal women seek support during the first two weeks after childbirth, due to the lack of physical and emotional support, low support perception, ineffective coping, problems with their child's health, problems in breastfeeding and, above all, postpartum complications. Health care providers are expected to develop a cultural awareness of their own cultural standards, beliefs and values, because, even though cultural competence has been recognized as a continuous, evolutionary, dynamic and developing process by most researchers, the current cultural competence models do not show any significant level of development of such competence ${ }^{(9)}$.

It is therefore essential that nurses are aware of the health care needs of the puerperal women that may be shaped by distinctive ways of being, of thinking and of acting and to be ready to, 
thanks to that appropriation of knowledge, provide them with the attention and the cultural respect they are entitled and deserve ${ }^{(4)}$.

\section{OBJECTIVE}

To identify the cultural care dimension in the interaction between nurses and puerperal women

\section{METHOD}

\section{Ethical issues}

Each and every ethical principle was respected and free and informed consent was previously obtained from each nurse and puerperal woman who participated in the study. The objectives were clarified, the participants' confidentiality and anonymity were ensured and they were informed that they could cease their collaboration at any given time.

Prior to data collection the project was submitted to the National Data Protection Commission and authorization to proceed was attained. The ethics committees of both institutions involved -one from the Região Centro (central region of Portugal) and the other from the Região Sul (southern region), were consulted, and the respective Administrative Boards issued a statement, authorizing the project.

\section{Theoretical and Methodological Framework}

The assumption was made that cultural standards $s^{(10)}$ include subjective, interactive and material dimensions that provide the scenarios that will guide people through their daily activities.

The main focus was trying to understand how puerperal women use cultural care information provided by nurses, in the social dynamics that includes obstetric care and that requires that nurses respect values, beliefs and practices that are part of the care they have to provide and that should be developed through a constant interaction between them and the puerperal women they work with.

\section{Type of study}

This is a descriptive study developed under a constructivist paradigm that used a qualitative research methodology and content analysis $^{(11)}$ (according to Bardin's perspective).

\section{Method}

To meet the objective previously defined, a method based on content analysis and on the application of semi-structured interviews was used. As soon as the institutional permission to conduct the study was granted, the head nurse of the service was approached and she was then responsible for introducing the participants and for providing the nurses and the puerperal women with any relevant information about the presence of the researchers.

Each researcher presented the study individually to a nurse or to one of the new mothers in a room where their privacy was ensured. One of the puerperal mothers was unable to participate because she had already been discharged from the hospital and her family was waiting for her.
A more detailed presentation of some elements (study settings, data source, data collection and organization and data analysis) is hereby provided.

\section{Study settings}

The current study was conducted in the obstetric service of two public Portuguese hospitals (one of them was located in the centre region and the other in the south region of the country) ${ }^{(11)}$.

\section{Data source}

Data was collected using semi-structured interviews that were applied to a sample composed of nurses and new mothers.

The sample selection criteria were the following: participants had to belong to the obstetric service and had willingly accepted to participate in the study.

As for the demographic characterization of the sample, 14 of the 15 nurses are Portuguese and the remaining nurse is Spanish. They have a mean age of 40.8 years. 19 of the 21 puerperal women are Portuguese, one of them is from Argentina and the last one is Ukrainian. The new mothers have a mean age of 32.29 years. $60 \%$ of the participants come from an institution located in the Região Centro (centre) and $40 \%$ come from an institution located in Região Sul (south) of Portugal.

\section{Data collection and organization}

The interviews were carried out by four researchers in a nursing office made available exclusively for this purpose, from August to October 2015 until data saturation was reached. Each interview was audio recorded and had an average duration of 45 minutes. Each respondent listened to his recording to make sure that she had said what she intended.

The interview script comprised two parts: the first contained nurses and mothers' demographic characterization variables; the second included the following guiding question: What kind of care is developed during nurse-puerperal mother interaction when cultural care is the goal we want to achieve? And another question: what does culturally competent nursing care means to you? - Comment based on your experience of caring for culturally-different patients ${ }^{(12)}$.

Data privacy was respected by assigning two-letter codes to the interviews. Puerperal mothers were assigned letter $\mathrm{P}$ and nurses were assigned letter $E$. This first letter was followed by another letter that corresponded to the order in which they were interviewed (ex; PA- $1^{\text {st }}$ puerperal woman interviewed; EA-1 ${ }^{\text {st }}$ nurse interviewed).

\section{Data analysis}

The tape recordings of each interview were transcribed and a qualitative analysis of the data obtained was carried out, following Bardin's content analysis method ${ }^{(13)}$ and using the Qualitative Analyses Software Certified Partner (NVivo version 10) programme. First, a pre-analysis was performed; data exploration was the following step and finally the treatment of the results was carried out, particularly through inference and interpretation. The different types of software available offer a wide range of possibilities for 
conducting qualitative analysis ${ }^{(14)}$. A set of categories and subcategories was designed from the data analyzed.

\section{RESULTS}

The results obtained from the analysis and from the codification of the interviews transcripts highlighted four categories of cultural significance (i) Nurses' attitudes that puerperal women consider to be crucial in health care provision; (ii) nurses' cultural competence; (iii) language resources used by nurses in their interaction with people from other cultures; (iv) limitations/ constraints observed during nurses-new mothers interactions.

The first category was evident in the puerperal mothers' words, the second and third categories were taken from the nurses' statements and the fourth category was present in the words of both nurses and mothers.

When the analysis of the puerperal mothers' answers was concluded, it was clear that they placed great significance to the attitudes they considered crucial in nurses'care provision. They attached greater importance to attitudes like nurses'ability to help, their concern, their friendliness, their competence and the fact that they were present when they needed their attention. Right after, they point out other fundamental attitudes like their professionalism, their willingness to show affection, to pay attention, to reassure them, their respect for singularity and their humanity. Table 1 presents a list of the less mentioned attitudes among puerperal women.

Table 1 - Nurses ' attitudes that puerperal mothers consider to be crucial in health care provision

\begin{tabular}{|c|c|c|c|}
\hline Category & Subcategories & $\mathbf{n}$ & $\mathbf{R U}$ \\
\hline \multirow{22}{*}{$\begin{array}{l}\text { Nurses' attitudes } \\
\text { that puerperal } \\
\text { mothers consider } \\
\text { to be crucial } \\
\text { in health care } \\
\text { provision }\end{array}$} & Their ability to help & 11 & 20 \\
\hline & Their concern & 10 & 13 \\
\hline & To be nice/friendly & 9 & 13 \\
\hline & To be present & 9 & 11 \\
\hline & Their competence & 8 & 11 \\
\hline & Their professionalism & 7 & 8 \\
\hline & To show kindness & 7 & 7 \\
\hline & To pay attention & 6 & 6 \\
\hline & To restore confidence & 5 & 8 \\
\hline & Their respect for singularity & 5 & 7 \\
\hline & Their humanity & 5 & 6 \\
\hline & Their collaborative attitude & 4 & 5 \\
\hline & To be patient & 4 & 4 \\
\hline & To be able to recognize differences & 3 & 4 \\
\hline & Their ability to comfort & 3 & 4 \\
\hline & To show readiness & 2 & 4 \\
\hline & Their capacity to be active listeners & 2 & 2 \\
\hline & To respond swiftly & 2 & 2 \\
\hline & Their capacity to provide proximity care & 2 & 2 \\
\hline & To reassure & 2 & 2 \\
\hline & Their willingness to provide support & 1 & 1 \\
\hline & Their politeness & 1 & 1 \\
\hline
\end{tabular}

The results also show the nurses' concerns for the mothers and their families'needs, although they are still struggling to find the right direction since culturally competent care requires some skills and knowledge such as: interest, readiness, engagement, communication, interaction, creativity and imagination and, above all, the capacity to see the other as a unique and singular being in his diversity.
In relation to the analysis categories that stemmed from the nurses words and expectations, their answers about the meaning of transcultural nursing led to the construction of a category that will help reflect on "nurses' cultural competence". The subcategories exhibited in Table 2 clearly voice their concerns about that issue. Of all those subcategories, "to respect people from other cultures" was the most referred to among nurses.

The participants' responses clearly showed that they were aware of the importance of some language resources like nurses' language skills and the presence of someone who could be capable of translating the patients' language (Table 3)

Table 2 - To exert cultural competence

\begin{tabular}{llcc}
\hline \multicolumn{1}{c}{ Category } & \multicolumn{1}{c}{ Subcategories } & n & RU \\
\hline To exert & To respect people from other cultures & 11 & 12 \\
cultural & To respond to the person's needs & 5 & 5 \\
competence & To be interested in knowing about other cultures & 5 & 5 \\
& The willingness to adapt to different cultures & 3 & 3 \\
& $\begin{array}{l}\text { To be able to learn about other cultures through } \\
\text { the interaction with puerperal women }\end{array}$ & 3 & 3 \\
& To establish an effective communication & 2 & 2 \\
& To possess knowledge about other cultures & 2 & 2 \\
& To understand the others to be able to & 1 & 1 \\
& understand ourselves & 1 & 1 \\
& To help understand other perspectives & & \\
\hline
\end{tabular}

Table 3 - Language resources used by nurses in their interaction with people from other cultures

\begin{tabular}{|c|c|c|c|}
\hline Category & Subcategories & $\mathbf{n}$ & RU \\
\hline \multirow{3}{*}{$\begin{array}{l}\text { Language resources used } \\
\text { by nurses in their interaction } \\
\text { with people from other } \\
\text { cultures }\end{array}$} & Nurses' different language skills & 2 & 2 \\
\hline & $\begin{array}{l}\text { A next of kin capable of translating } \\
\text { the patient's language }\end{array}$ & 1 & 2 \\
\hline & Hospital translators/interpreters & 1 & 1 \\
\hline
\end{tabular}

Table 4 - Limitations/constraints observed during nurses- puerperal mothers interactions

\begin{tabular}{|c|c|c|c|c|}
\hline Category & & Subcategories & $\mathbf{n}$ & RU \\
\hline \multirow{7}{*}{$\begin{array}{l}\text { Limitations/ } \\
\text { constraints } \\
\text { observed during } \\
\text { nurses- puerperal } \\
\text { mothers } \\
\text { interactions }\end{array}$} & \multirow{3}{*}{$\begin{array}{l}\text { Constraints } \\
\text { expressed by } \\
\text { nurses }\end{array}$} & $\begin{array}{l}\text { The lack of knowledge } \\
\text { about other cultures }\end{array}$ & 7 & 8 \\
\hline & & $\begin{array}{l}\text { A poor knowledge about } \\
\text { cultural care }\end{array}$ & 3 & 5 \\
\hline & & $\begin{array}{l}\text { The conviction that some } \\
\text { beliefs are wrong }\end{array}$ & 1 & 1 \\
\hline & \multirow{4}{*}{$\begin{array}{l}\text { Constraints } \\
\text { expressed by } \\
\text { puerperal mothers }\end{array}$} & $\begin{array}{l}\text { A poor support caused } \\
\text { by the nurse-patient ratio }\end{array}$ & 2 & 4 \\
\hline & & $\begin{array}{l}\text { The lack of constant } \\
\text { support during breast } \\
\text { feeding }\end{array}$ & 1 & 1 \\
\hline & & $\begin{array}{l}\text { The technical jargon } \\
\text { used by health care } \\
\text { providers }\end{array}$ & 1 & 1 \\
\hline & & A poor knowledge & 1 & 1 \\
\hline
\end{tabular}

In Table 4, the limitations/constraints that were recognized in the interactions between nurses and puerperal mothers are presented. Two of the subcategories were created to address the nurses' concerns and five were based on the mothers' expectations. 
The constraints expressed by nurses pointed out their ignorance of other cultures and the lack of training in transcultural nursing.

The mothers' discourse raised a few issues related to the cultural differences that risk causing some insecurity and fear of being misunderstood. In their opinion, the most important constraint/limitation is the poor support provided due to the insufficient nurse-patient ratio, leading to an incomplete knowledge of the patient and to a lack of understanding of the technical language used by nurses

\section{DISCUSSION}

The dimension that covers "Nurses' attitudes that the puerperal mothers consider to be crucial in health care provision" reflects the importance of culturally competent care as a relevant element of nursing care social context and of maternal health nursing and is crucial to show the critical attributes one commonly associates with cultural competence. The development of cultural skills in health professions is considered an essential condition for promoting quality and equity in health care ${ }^{(9)}$.

Nurses' care attitude that puerperal mothers valued the most was their ability to help. This clearly shows how important this facet is for puerperal women and how it helps them understand how meaningful nursing care is and realize that this kind of health care is a crucial help during childbirth. Some of the sentences transcribed below show the importance attached to this subcategory.

[Nurses] are always very willing to help. (PD)

[Nurses] have always been helpful and cooperative since day one. (PE)

It is gratifying [to be cared for by nurses] because they help us. If the babies were handed to us without any additional help, we wouldn't know what to do especially those of us who are mothers for the first time... [...] (PO)

They help us to get ready to take care of the baby. (PL)

I have always received their full support and help, nurses took such good care of me. (PS)

The concern shown by nurses as they were providing care was another attitude that was extremely appreciated by puerperal women and was referred by ten of them. Other attitudes were highly valued as well: nine mothers stressed the nurses'kindness and the fact that they were always present when their help was needed; eight of them pointed out their competence; seven new mothers referred their professionalism and their tenderness; six of the new mothers stated that they have appreciated the way they paid attention to their needs; and five of them highlighted how they were able to reassure them, to give them the right confidence, the respect they have shown for each patients' singularity and their humanity.

Other attitudes included in this category were less valued: nurses' collaborative attitude and patience, for instance were subcategories referred by four respondents only; their ability to recognize the differences and to comfort their patients were mentioned by three respondents; their readiness, their capacity to be active listeners and to provide swift response and to provide proximity care were mentioned by two mothers only and their support and politeness were referred by one of the new mothers.

These attitudes are fundamental to health care providers who are interested in developing a quality and proximity interaction with the new mothers. Parreira ${ }^{(15)}$ refers that regardless of their cultural values and beliefs, all post-natal women need to feel supported and watched over and feel that they are entitled to be treated with the highest professionalism, quality and competence by those who provide health care. Caregivers' interaction and communication skills can make global health and well-being a lot easier ${ }^{(16)}$, for both national and foreign patients ${ }^{(17)}$.

As for the category that covers "nurses' cultural competence", nine subcategories were designed: to respect people of other cultures, to respond to the person's needs, to be interested in knowing other cultures, the willingness to adapt to the different cultures, to be able to learn about other cultures through the interaction with puerperal women, to establish an effective communication, to possess knowledge of other cultures, to understand the others so we can understand ourselves and to help understand other perspectives. Taking into account the statements analysed, it is important to emphasize the nurses' knowledge regarding the provision of culturally congruent care, as well as their efforts to develop a practice of caring that focuses on cultural competence.

This is what nursing is all about, we have to realize what it truly is, what the other person's culture is and adapt to that new situation. (EA)

There are other cultures that may not accept certain behaviours that we adopt over here, treatments and procedures that we carry out and we need to know how to understand those people and adjust to their culture. (EB)

We must take care of the patients according to their cultural needs and meet the needs of each and every one of them. (EN)

Purnell \& Paulanka ${ }^{(6)}$ claim that cultural consciousness leads to greater satisfaction with the health care provided, because it reduces contexts that may generate inequalities of treatment based on gender, ethnicity and race, and many others, that will cause constraints and jeopardize the quality of health care. With globalization, societies have become increasingly multicultural and, therefore, nurses must continually acquire new knowledge that will make them more aware and more qualified to deal with their "clients' specificities"(18).

In this regard, there were signs, in one of the nurses' intervention, of a certain type of ethnocentrism and of something that might be seen as an attempt at imposing personal cultural values over someone else's, when that practitioner pointed out she was trying to help the puerperal mother to consider other medical perspectives she believed were much better.

There are things we want to teach and that are done differently in their culture and it's very complicated. (EK)

The category that deals with "language resources used by nurses in their interaction with people from other cultures" was subdivided into three subcategories that address the strategies 
used to ensure effective communication between nurses and puerperal women. Nurses are expected to develop an effective relationship with these new mothers and to succeed in improving their general well-being and their family's well-being as well.

When you provide care to people from different cultures, you must pay particular attention to the type of communication that you establish with them, because the asymmetry between the interlocutors may distort the message and what is said can result in an entirely different outcome from the one intended.

Purnell and Paulanka ${ }^{(6)}$ advise health providers to choose words that have relatively "pure" meanings and draw attention to the importance of using the right voice volume, tone and intonation depending on the communicational context. They also stress the importance of not translating individual words, since they can, as it may happen with pronunciation variations, change the meaning of words and sentences and cause inappropriate situations. Other authors ${ }^{(19)}$ point out the sense of ambivalence felt by nurses when there are interpreters involved, whether they are relatives or not. On the one hand, the presence of the translator/interpreter can cause embarrassing and disturbing situations but, on the other hand, his/her presence is necessary for the communication between care provider and patient to be effective and fruitful. On the other hand, during childbirth women go through situations that involve aspects of their private life and choosing a relative to act as interpreter may place the puerperal mother in a rather uncomfortable position: she will have to reveal intimate aspects of her life to a family member, a situation that might cause embarrassment and that might even jeopardize her well-being and her child's or she might withhold valuable information from the nurse. Such situation will also cause constraints and might affect her well-being and her health.

These constraints will be overcome or minimized with the presence of an intercultural mediator ${ }^{(12,20)}$ who, on the one hand, respects the puerperal mother's privacy and, on the other hand, understands the significance of the experience she is going through while evidencing righteousness and a great capacity to help ${ }^{(21)}$.

As far as the constraints experienced in nurses-mothers interactions (as described in the "nurses' cultural competence" category), it is clear that, even though nurses can always learn about other cultures through direct contact with the mothers, this kind of experience is not enough for them to obtain the cultural knowledge they need to achieve a culturally sensitive practice. This conclusion was supported by the statements given by seven of the nurses who mentioned their lack of knowledge about other cultures and by the poor training in transcultural nursing reported by two other nurses.

\begin{abstract}
... because, when it comes to cultural heritage, I do not have enough information to know whether or not my behaviour will cause any kind of discomfort to people [...] If I don't do any of that, it's because I don't know how to do it. (EI)
\end{abstract}

If I have to provide care to a Muslim lady again, I would pay much more attention ... I honestly was not aware of the implications... it never occurred to me that the presence of a man would cause so much trouble. (EL)

Another limitation that stemmed from one of the nurse's words had to do with the fact that some people truly think that some beliefs are wrong, a position that uncovers a certain desire for cultural imposition. Some new mothers became aware of the cultural inability that was affecting nurses' actions and attitudes. This discomfort was caused by the poor support they were provided with and that was caused by the nurse-patient ratio implemented, by the lack of constant support during breast feeding, the technical (and hard to understand) jargon used by nurses and other health providers and the poor knowledge evidenced. This evidence is also supported by others ${ }^{(8,22)}$ who commented on the insufficient support provided, an issue that includes the lack of continuity of care and an inadequate mental and emotional health support that is often provided to puerperal women.

Even though they understand that there can't be a nurse for each woman, those new mothers once again stressed the lack of support they felt. That position is evident in the following statement:

I understand that you cannot have a nurse for every patient, there are so many people, but all I wanted was their attention and support. (PP)

Their inability to understand the technical language used by nurses and the nurses' poor knowledge were other additional constraints experienced by those puerperal women. In this context,

the need for an effective intercultural interconnection between nurses and postpartum mothers becomes evident: nurses sometimes have no critical awareness about professional culture, they sometimes fail to understand that puerperal mother will have a hard time trying to understand the concepts and terms used in professional culture and that this confusion may give rise to negative feelings. This uncomfortable sensation confirms the version suggested by other studies: nurses do things but they do not explain them.

It is essential to recognize that cultural competence in nursing goes beyond cultural, sensitive and adequate responses. People need to understand the intentionality of actions. In this regard, the competent approach covers the understanding of the interactions between nurses and postpartum mothers that includes a critical awareness of actions, conducts and of the impact they might have.

Good practices are associated with the valorisation of the understanding of such feelings and of their expression as therapeutic intervention, since those feelings can have an impact on the postpartum women's health and well-being ${ }^{(23)}$ and can trigger negative emotions in their experience and adjustment to motherhood. On the other hand, the conduct adopted by some women, their life choices, may have direct implications on the child ${ }^{(24)}$.

In certain societies and cultures pregnancy is lived differently according to their adopted concepts, beliefs, values, myths, traditions and culture. This reality requires nurses to internalize every bit of knowledge, every sort of experienced practice and to take into account the way people to whom they provide health care live and act. They will also have to master the suitable language resources ${ }^{(25)}$ that will, during their interaction with puerperal mothers, determine the adequacy and effectiveness of the cultural care.

\section{Study limitations}

Data collection for this qualitative study was carried out by four different researchers, each one of them influenced by his own 
Nurses- puerperal mothers interaction: searching for cultural care Coutinho E, Amaral S, Parreira MVBC, Chaves CB, Amaral O, Nelas P.

subjectivity and his particular focus on the matter, with different experiences and life stories, with different and personal ways to conduct an interview. This realization is, in itself, a limitation. When we are dealing with a certain object or question, we are perfectly aware that the knowledge possessed by each researcher will influence the way he looks and interprets that object and that the point of view elected by each researcher is unique and specific. Data validation carried out by all researchers involved was the solution found to control researcher bias.

Another limitation has to do with the fact that the sample has been selected according to nurses and mothers' availability and not according to the ability of each participant to report the experience. As for the quality of nursing qualitative research ${ }^{(26)}$, adopting a research supported by Criteria for Evaluation and Construction of Qualitative Studies would be quite useful since those models will make the authors' work much easier throughout the research and when time comes to prepare the article ${ }^{(27)}$.

\section{Contributions made to nursing practice, health care or public policy}

This qualitative research study allowed to understand the meaning that nurses and mothers give to the interventions they built during interaction of care, focusing on culturally competent obstetric nursing care. It revealed information about some of the nurses' attitudes that puerperal mothers consider indispensable during the process of caring, about the type of work developed by nurses in order to improve their cultural competence, about the language resources used by nurses in their interactions with foreign people and the fact that there's no reference of the presence of a cultural mediator during childbirth and the post-partum treatments. Another valuable aspect that stemmed from the study was the type of limitations/constraints observed in nurses-mothers interactions and the implications they might have on nursing practice. These observations are essential to set an action path that participants will have to follow and reveal that nurses consciously feel the need for a certain kind of training that will provide them with greater knowledge about the specifics and contributions that are crucial to achieve the development of professional cultural competence. Taking these considerations into account, a higher investment is suggested in the training and self-training offered to health care providers. It is worth noting the added value that this kind of training may represent in the improvement of health programs already implemented, in the quality of nursing education institutions and in nurses' initial and postgraduate nursing training.

\section{CONCLUSION}

In the cultural environment in which this study was conducted, there seems to be an agreement between puerperal mothers and nurses.

On the one hand, the mothers recognize that nurses' attitudes (like the help they provide and their readiness) are indispensable to the process of caring. Nurses value the efforts they make to improve their cultural competence and to respect people from other cultures; they also realize the importance of the linguistic resources used in the interaction (resources that include their own linguistic knowledge) as a facilitating factor for cultural competence, of the existence of translators/interpreters in hospitals and they also realize how important is the presence of a next to kin who is able to translate the puerperal mothers' messages or solicitations, despite all the constraints that such a presence may entail to those women.

On the other hand, nurses and mothers pointed out some constraints that might upset their interaction. Some nurses are unable to realize that cultural competence is much more than making contact with foreign people and that it concerns any person regardless of his/her culture; some others have accepted their cultural incompetence and, as a consequence, referred that they really need to deepen and acquire greater knowledge about interculturality. On the other hand, some of the new mothers revealed that they could feel this lack of support from nurses in the way they handled breast feeding situations and in the discomfort caused by the technical/medical jargon used by some nurses during their interactions that made their indications and messages unintelligible. These constraints, and the fact that none of the inquired nurses had referred the need for an intercultural mediator, show that there is yet a lot to achieve in terms of nursing training to provide health care agents with the right critical awareness that will enable them to unwittingly become culturally competent.

\section{FUNDING}

This study is funded through national funds by the Portuguese Foundation for Science and Technology (FCT) in the scope of project UID / Multi / 04016/2016. Funding sipoorted by FCT and CIDETS - Centro de Estudos em Educação Tecnologia e Saúde, Portugal.

\section{ACKNOWLEGDEMENTS}

Thanks are due to Polytechnic Institute of Viseu, CI\&DETS, High Commission for Migration in the scope of the Network of Intercultural Mediation in Higher Education (RESMI) and Chapter Phi Xi - Sigma Theta Tau International

\section{REFERENCES}

1. Leininger M. Transcultural nursing pespectives: basic concepts, principles, and culture care incidents. In: Leininger M, (Ed). Transcultural nursing: concepts, theories, research \& practices. 2nd ed. New York: McGraw-Hill; 1998.

2. Sagar P. Transcultural nursing theory and models: application in nursing education, practice, and administration. New York: Springer; 2012.

3. Parreira V, Coutinho E, Néné $M$. A competência cultural e a prática de enfermagem no processo de maternidade. In: Néné M, Marques R, Batista MA, (Eds). Enfermagem de saúde materna e obstétrica. Lisboa: Lidel; 2016.

4. Campinha-Bacote J. Delivering patient-centered care in the midst of a cultural conflict: the role of cultural competence. Online J Issues Nurs. 
2011;16(2):5. doi: https://doi.org/10.3912/OJIN.Vol16No02Man05

5. Pretceille M. L'éducation interculturelle. Paris: PUF; 2017.

6. Purnell L, Paulanka B. Cuidados de saúde transculturais: uma abordagem culturalmente competente. Loures (PT): Lusodidacta; 2010.

7. Debiasi LB, Selleck CS. Cultural competence training for primary care nurse practitioners: an intervention to increase culturally competent care. J Cult Divers[Internet]. 2017[cited 2017 Dec 05];24(2):39-45. Available from: https://www.questia.com/library/journal/1P4-1974490916/ cultural-competence-training-for-primary-care-nurse

8. Barimani M, Oxelmark L, Johansson S-E, Hylander I. Support and continuity during the first 2 weeks postpartum. Scand J Caring Sci [Internet]. 2015 [cited 2017 Dec 05];29(3):409-17. Available from: https://doi.org/10.1111/scs.12144

9. Blanchet Garneau A, Pepin J. Cultural competence: a constructivist definition. J Transcult Nurs [Internet]. 2015[cited 2017 Dec 05];26(1):9-15. Available from: https://doi.org/10.1177/1043659614541294

10. Elliot G. Cracking the cultural competency code. Can J Nurs Res. 2006;17(4):12-24.

11. Coutinho E, Amaral S, Parreira V, Chaves C, Amaral O, Nelas P. O cuidado cultural na trajetória da enfermagem transcultural e competência cultural. Inv Qual Saúde [Internet]. 2017 [cited 2019 Mar 15];2:1578-87. Available from: https://proceedings.ciaiq.org/index.php/ciaiq2017/ article/view/1510/1467

12. Coutinho E, Parreira V, Martins B, Chaves C, Nelas P. The informal intercultural mediator nurse in obstetrics care. In: Costa AP, Reis LP, Souza FN, Moreira A, Lamas D. Computer supported qualitative research. Switzerland: Springer; 2017.

13. Bardin L. Análise de conteúdo. Lisboa: Edições 70; 2015.

14. Costa AP, Souza FN, Souza DN. Trabalho colaborativo na investigação qualitativa através das tecnologias. In: Souza DN, Costa AP, Souza FN, editors. Investigação qualitativa: inovação, dilemas e desafios. Vol. 3. Oliveira de Azeméis (PT): Ludomedia; 2016. p. 105-27.

15. Parreira V. Maternidade: da natureza à cultura: parto e sua complexidade sociocultural. Rev Ass Port Enf Obst. 2007;(8):19-23.

16. Haugan G. Nurse-patient interaction is a resource for hope, meaning in life and self-transcendence in nursing home patients. Scand J Caring Sci [Internet]. 2014 [cited 2017 Dec 05];28(1):74-88. Available from: https://doi.org/10.1111/scs.12028

17. Silva RGM, Possas CRSS, Barbosa MR, Araujo HF, Santos MSC. [Nurse communication strategies with foreign patients: experience report]. Arq Cienc Saude UNIPAR [Internet]. 2016 [cited 2017 Dec 05];20(2):145-8. Available from: https://doi.org/10.25110/arqsaude.v20i2.2016.5219 Portuguese.

18. Maier-Lorentz MM. Transcultural nursing: its importance in nursing practice. J Cult Divers. 2008;15(1):37-43.

19. Skott C, Lundgren SM. Complexity and contradiction: home care in a multicultural area. Nurs Inq. 2009;16(3):223-31. doi: https://doi. org/10.1111/j.1440-1800.2009.00454.x

20. Giménez-Romero C. [La naturaleza de la mediación intercultural]. Rev Migr [Internet]. 1997 [cited 2017 Dec 05];2:125-59. Available from: http://revistas.upcomillas.es/index.php/revistamigraciones/article/view/4888 Spanish.

21. Meleis Al. Transitions theory middle-range and situation-specific theories in nursing research and practice. New York: Springer Publishing Company; 2010

22. Almalik M. Understanding maternal postpartum needs: a descriptive survey of current maternal health services. J Clin Nurs. 2017;26:465463. doi: https://doi.org/10.1111/jocn.13812

23. Nelas P, Coutinho E, Chaves C, Amaral O, Cruz C. Dificuldades na amamentação no primeiro mês de vida: impacto dos contextos de vida. Int J Dev Educ Psychol [Internet]. 2017 [cited 2017 Dec 05];3(1):183-92. Available from: http://www.redalyc.org/html/3498/349853365019/

24. Mendes IM. Ajustamento materno e paterno: experiências vivenciadas pelos pais no pós parto. Coimbra (PT): Mar da Palavra; 2009.

25. Governo de Portugal. ACM: Alto Comissariado para as Migrações. Serviço de Tradução Telefónica[Internet]. Available Portugal: ACM; c2018 [cited 2018 Mar 27]. Available from: https://www.acm.gov.pt/pt/-/servico-de-traducao-telefonica\#

26. Egry EY, Fonseca RMGSF. Acerca da qualidade nas pesquisas qualitativas em enfermagem. In: Souza DN, Costa AP, Souza FN, editors. Investigação qualitativa: inovação, dilemas e desafios. Oliveira de Azeméis (PT): Ludomedia; 2015. p. 75-102.

27. Costa AP, Souza FN. Critérios de avaliação e construção de artigos em investigação qualitativa (CACAIQ). In: Costa AP, Souza FN, Souza DN, editors. A prática na investigação qualitativa: exemplos de estudos. Oliveira de Azeméis (PT): Ludomedia; 2017. p. 17-25. 